\title{
Family-based Development Model
}

\author{
Harsuko Riniwati ${ }^{1}$, Fadilla Putra $^{2}$, Wike $^{3}$ \\ \{riniwatisepk@ub.ac.id ${ }^{1}$ \} \\ Universitas Brawijaya, Indonesia ${ }^{1,2,3}$
}

\begin{abstract}
Family has become the foundation of the achievement of development goals, global security and world prosperity for Indonesian generations. It is evidently necessary to formulate a family-based development model. This study aims to analyze 1) the indicators of factors affecting family resilience and adaptability, 2) the influence of social, cultural, economic, environmental and security factors to family adaptability. The research method used was Structural Equation Modeling. Data was obtained from mothers and children of 482 families in Pasuruan Regency. Data analysis employed smart Part Least Square (smart PLS). The result showed that 1) social variable positively and significantly affected family resilience, 2) social variable positively and significantly affected family adaptability, 3) economic variable had no significant effect on family resilience, 4) economic variable negatively and significantly affected family adaptability, 5) Cultural variable positively and significantly affected family resilience, 6) Cultural variable did not significantly affect family adaptability, 7) Environmental variable positively and significantly affected family resilience, 8) Environmental variable had no significant effect on family adaptability, 9) The family security variable positively and significantly affected family adaptability. This research concludes that family resilience is a strong mediator through social, cultural and environmental variables in dealing with family adaptability. The positive relationship between family resilience and adaptability shows that the policy is implementing gender and development (GAD) paradigm.
\end{abstract}

Keywords: Family Resilience, Family Adaptability, Women in Development (WID), Gender in Development (GID), Gender and Development (GAD).

\section{Introduction}

Family is the smallest unit of a society. Family development will create a quality family living in a healthy environment, characterized by being prosperous, healthy, progressive, independent, having an ideal number of children, forward-looking, responsible, harmonious and devoted to God [1].

Family-based development must be conducted professionally and optimally. The concept of family-based development must be socialized as early as possible. It may begin with an improvement in education and training, which results in productive human resources capable to manage existing potential and resources. Family-based development shall maintain sociocultural values and the context of local wisdom.

Family-based development in Pasuruan Regency refers to the system model by White and Klein [2], incorporating the individual model by Hill and Duvall [3]. Pasuruan Regency not only puts forward secular social values, including the level of education, health, economy and so on, it also considers religious values important. Hence the needs for an in-depth study of how secular values are integrated with religious values and how integrated values penetrate 
and are internalized in a family. How successful the internalization of these values is measured by utilizing development indicators such as HDI, participation rates, MMR/IMR, unemployment rates, and regional economic growth.

The number of households in Pasuruan Regency in 2017 was 438,580 (East Java BPS, 2017). This large number places Pasuruan Regency in the sixth place out of 38 Regencies/Cities in East Java.

\section{Research Objectives}

a) To analyze the indicators of social, economic, cultural, environmental, family resilience and family adaptability variables.

b) To analyze the relationships among social, economic, cultural, environmental variables on family resilience.

c) To analyze the effect of the relationships among social, economic, cultural, environmental and family resilience variables on family adaptability.

d) To formulate a family-based development model.

\section{Research methods}

This research used structural equation modeling, requiring a theory-based conceptual model to be tested. The model resulted from the literature review is presented below:

\subsection{Theory-based model}

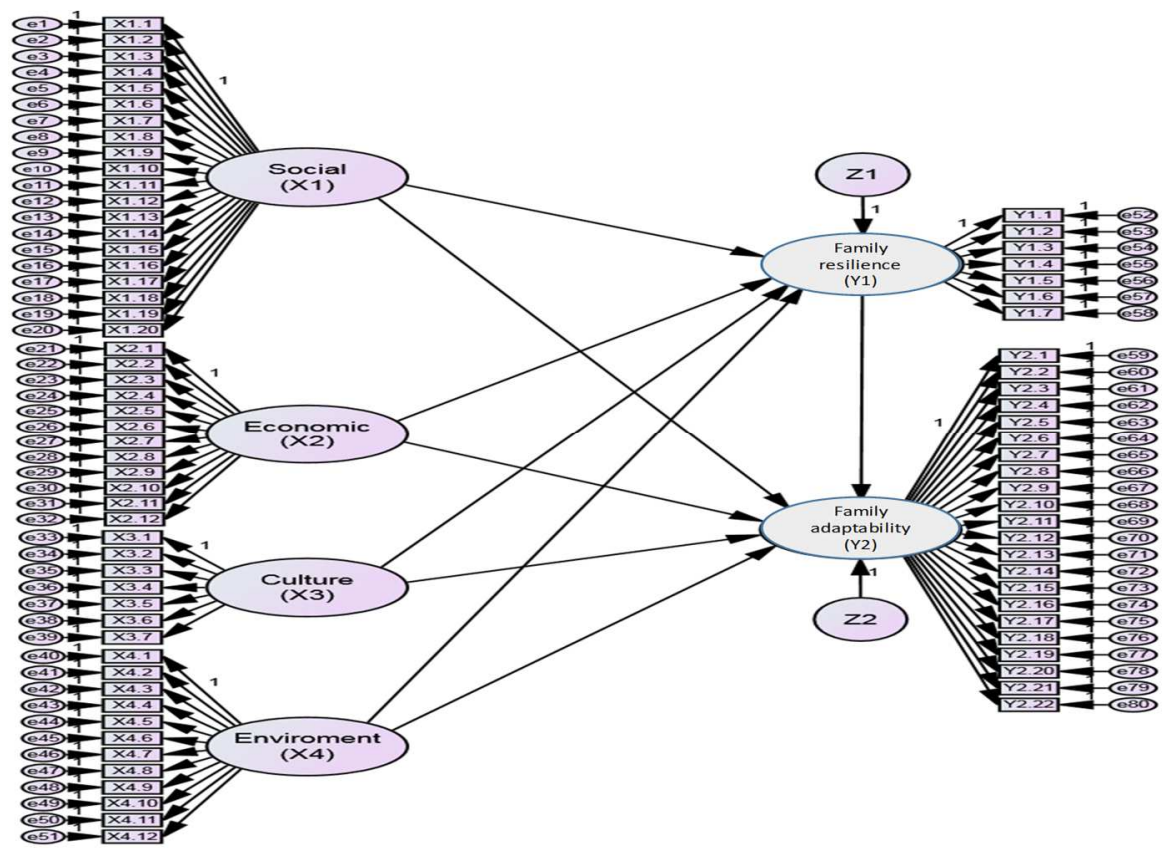




\subsection{Research Design}

This study used an explanatory research design which provides an elaboration of the causal relationship among variables through hypotheses testing using a quantitative approach. Causal relationships occur between 2 or more variables [4]-[6].

\subsubsection{Population, Sample and Sample Selection Technique}

a) Population and Sample

The population in this study included all residents of Pasuruan Regency. The sample included mothers and children and sub-district heads from each district in Pasuruan Regency. According to Ferdinand [7], the total sample is the number of indicators multiplied by 5-10. The number of indicators was 80 . The minimum total of samples was $80 \times 5=400$.

b) Sample Selection Technique

The sample selection used stratified random sampling based on the number of villages in each sub-district. The composition of samples per each district according to the modification formula, between the minimum sample size for structural and strata model is described as follows:

Sample Percentage $=($ number of villages per sub-district: total number of villages) $\times 100 \%$

Minimum number of samples $=5$ n number of indicators $=5 \times 80=400$ people

Number of samples per district $=$ percentage of samples $\mathrm{x}$ minimum number of samples

Total number of villages $=366$

The number of questionnaires filled out by 482 respondents indicated that the number of respondents had fulfilled the rule as it exceeded the minimum number of samples.

\subsection{Classification of Research Variables}

This study discusses five types of variables, including:

a) Social Variable $\left(\mathrm{X}_{1}\right)$, as an exogenous variable (Independent Variable)

b) Economic Variable $\left(\mathrm{X}_{2}\right)$, as an exogenous variable (Independent Variable)

c) Economic Variable $\left(\mathrm{X}_{3}\right)$, as an exogenous variable (Independent Variable)

d) Environmental Variable $\left(\mathrm{X}_{4}\right)$, as an exogenous variable (Independent Variable)

e) Family resilience Variable $\left(\mathrm{Y}_{1}\right)$, as an endogenous variable (Dependent variable)

f) Family adaptability Variable $\left(\mathrm{Y}_{2}\right)$, as an endogenous variable (Dependent variable)

\subsubsection{Operational Variable Definition}

a) Social $\left(\mathrm{X}_{1}\right)$

Social Variable $\left(\mathrm{X}_{1}\right)$, was measured by utilizing 20 indicators, including security $\left(\mathrm{X}_{1.1}\right)$, peace $\left(X_{1.2}\right)$, hope for a better future $\left(X_{1.3}\right)$, prosperity $\left(X_{1.4}\right)$, Health $\left(X_{1.5}\right)$, Progress $\left(X_{1.6}\right)$, Independence $\left(\mathrm{X}_{1.7}\right)$, Ideal number of children $\left(\mathrm{X}_{1.8}\right)$, Responsibility $\left(\mathrm{X}_{1.9}\right)$, Harmonious living $\left(\mathrm{X}_{1.10}\right)$, Devotion $\left(\mathrm{X}_{1.11}\right)$, Self-reliance $\left(\mathrm{X}_{1.12}\right)$, physical and mental happiness $\left(\mathrm{X}_{1.13}\right)$, 
education $\left(\mathrm{X}_{1.14}\right)$, spiritual $\left(\mathrm{X}_{1.15}\right)$, division of roles $\left(\mathrm{X}_{1.16}\right)$, support for progress $\left(\mathrm{X}_{1.17}\right)$, family time $\left(\mathrm{X}_{1.18}\right)$, social interaction $\left(\mathrm{X}_{1.19}\right)$, and problem solving $\left(\mathrm{X}_{1.20}\right)$.

Each indicator was a measurement of the responses or opinions of respondents (mothers, children and village and sub-district officials/staff) recorded in the questionnaire. Measurement of these indicators used an interval scale with a score of 1-10.

b) Economic $\left(\mathrm{X}_{2}\right)$

Economic variable $(\mathrm{X} 2)$ was measured by utilizing 12 indicators, including salary $\left(\mathrm{X}_{2.1}\right)$, bonus $\left(\mathrm{X}_{2.2}\right)$, savings $\left(\mathrm{X}_{2.3}\right)$, livelihood $\left(\mathrm{X}_{2.4}\right)$, job opportunity $\left(\mathrm{X}_{2.5}\right)$, unemployment $\left(\mathrm{X}_{2.6}\right)$, entertainment $\left(\mathrm{X}_{2.7}\right)$, clothing $\left(\mathrm{X}_{2.8}\right)$, food $\left(\mathrm{X}_{2.9}\right)$, home $\left(\mathrm{X}_{2.10}\right)$, transportation $\left(\mathrm{X}_{2.11}\right)$, business state $\left(\mathrm{X}_{2.12}\right)$,

\section{c) Cultural (X3)}

Cultural variable $\left(\mathrm{X}_{3}\right)$ was measured by utilizing 7 indicators, including family's capability to overcome non-physical problems $\left(\mathrm{X}_{3.1}\right)$, physical emotional control $\left(\mathrm{X}_{3.2}\right)$, positive selfimage $\left(\mathrm{X}_{3.3}\right)$, spousal care $\left(\mathrm{X}_{3.4}\right)$, children respecting parents $\left(\mathrm{X}_{3.5}\right)$, work ethic $\left(\mathrm{X}_{3.6}\right)$, positive activities $\left(\mathrm{X}_{3.7}\right)$.

d) Environmental (X4)

Environmental variable $\left(\mathrm{X}_{4}\right)$ was measured by utilizing 12 indicators, including family's capability in dealing with air quality $\left(\mathrm{X}_{4.1}\right)$, water quality $\left(\mathrm{X}_{4.2}\right)$, soil quality $\left(\mathrm{X}_{4.3}\right)$, forest quality $\left(\mathrm{X}_{4.4}\right)$, beach, sea quality $\left(\mathrm{X}_{4.5}\right)$, rice field quality $\left(\mathrm{X}_{4.6}\right)$, superior product quality $\left(\mathrm{X}_{4.7}\right)$ disasters $\left(\mathrm{X}_{4.8}\right)$, waste generation $\left(\mathrm{X}_{4.9}\right)$, waste management $\left(\mathrm{X}_{4.10}\right)$, refuse generation $\left(\mathrm{X}_{4.11}\right)$, refuse management $\left(\mathrm{X}_{4.12}\right)$

e) Family resilience (Y1)

Family resilience variable $\left(\mathrm{Y}_{1}\right)$ was measured by utilizing 7 indicators, including trying to do something for others $\left(\mathrm{Y}_{1.1}\right)$, doing and walking together $\left(\mathrm{Y}_{1.2}\right)$, family maintenance $\left(\mathrm{Y}_{1.3}\right)$, creating a positive atmosphere $\left(\mathrm{Y}_{1.4}\right)$, protecting shared dignity and celebrating life together $\left(\mathrm{Y}_{1.5}\right)$, the ability of individuals or families to explore their potential to face life's challenges $\left(\mathrm{Y}_{1.6}\right)$, the ability of families to manage problems utilizing the resources they have to meet needs $\left(\mathrm{Y}_{1.7}\right)$.

\section{f) Family adaptability (Y2)}

Family adaptability variable $\left(\mathrm{Y}_{2}\right)$ was measured by utilizing 22 indicators, including: No abandoned $<5$-year-old children $\left(\mathrm{Y}_{2.1}\right)$, no abandoned children $\left(\mathrm{Y}_{2.2}\right)$, no 'bad' children $\left(\mathrm{Y}_{2.3}\right)$, no homeless children $\left(\mathrm{Y}_{2.4}\right)$, no socially and economically vulnerable women $\left(\mathrm{Y}_{2.5}\right)$, no victims of violence $\left(\mathrm{Y}_{2.6}\right)$, no abandoned elderly people $\left(\mathrm{Y}_{2.7}\right)$, no abandoned, disabled family members $\left(\mathrm{Y}_{2.8}\right)$, no unemployed family members $\left(\mathrm{Y}_{2.9}\right)$, no beggars in the family $\left(\mathrm{Y}_{2.10}\right)$, no homeless family members $\left(\mathrm{Y}_{2.11}\right)$, no ex-convicts $\left(\mathrm{Y}_{2.12}\right)$, no drug abuse $\left(\mathrm{Y}_{2.13}\right)$, no poor family members $\left(\mathrm{Y}_{2.14}\right)$, no family members living in unhabitable homes $\left(\mathrm{Y}_{2.15}\right)$, no family members with social and psychological problems $\left(\mathrm{Y}_{2.16}\right)$, no remote indigenous communities $\left(\mathrm{Y}_{2.17}\right)$, no victims of natural disasters $\left(\mathrm{Y}_{2.18}\right)$, no victims of social disasters/refugees $\left(\mathrm{Y}_{2.19}\right)$, no migrant workers with social problems $\left(\mathrm{Y}_{2.20}\right)$, no family members with HIV/AIDS $\left(\mathrm{Y}_{2.21}\right)$, no vulnerable family members $\left(\mathrm{Y}_{2.22}\right)$. 


\subsection{Research Instrument}

\subsubsection{Type of Instrument}

The instrument used in this study was a questionnaire with answers in the interval data scale of 1 to 10 as shown in the following table:

Table 1. Family-Based Development Research Questionnaire

\begin{tabular}{|c|c|c|c|c|c|c|c|c|c|c|c|}
\hline & Indicator (Quantitative) & 1 & 2 & 3 & 4 & 5 & 6 & 7 & 8 & 9 & 10 \\
\hline I & Social (X1) & & & & & & & & & & \\
\hline 1 & Security (X1.1) & & & & & & & & & & \\
\hline 2 & Peace (X1.2) & & & & & & & & & & \\
\hline 3 & $\begin{array}{l}\text { Hope for a better future in realizing } \\
\text { physical well-being and inner happiness } \\
\text { (X1.3) }\end{array}$ & & & & & & & & & & \\
\hline 4 & Prosperity (X1.4) & & & & & & & & & & \\
\hline 5 & Health (X1.5) & & & & & & & & & & \\
\hline 6 & Progress (X1.6) & & & & & & & & & & \\
\hline 7 & Independence $(\mathrm{X} 1.7)$ & & & & & & & & & & \\
\hline 8 & Ideal number of children (X1.8) & & & & & & & & & & \\
\hline 9 & Responsibility (X1.9) & & & & & & & & & & \\
\hline 10 & Harmonious living (X1.10) & & & & & & & & & & \\
\hline 11 & Devotion (X1.11) & & & & & & & & & & \\
\hline 12 & Self-reliance (X1.12) & & & & & & & & & & \\
\hline 13 & Physical/mental happiness (X1.13) & & & & & & & & & & \\
\hline 14 & Education (X1.14) & & & & & & & & & & \\
\hline 15 & Spiritual (X1.15) & & & & & & & & & & \\
\hline 16 & Division of roles (X1.16) & & & & & & & & & & \\
\hline 17 & Support for progress (X1.17) & & & & & & & & & & \\
\hline 18 & Family time (X1.18) & & & & & & & & & & \\
\hline 19 & Social interaction (X1.19) & & & & & & & & & & \\
\hline 20 & Problem solving (X1.20) & & & & & & & & & & \\
\hline II & Economic $(\mathrm{X} 2)$ & & & & & & & & & & \\
\hline 1 & Salary $(\mathrm{X} 2.1)$ & & & & & & & & & & \\
\hline 2 & Bonus (X2.2) & & & & & & & & & & \\
\hline 3 & Savings (X2.3) & & & & & & & & & & \\
\hline 4 & Livelihood (X2.4) & & & & & & & & & & \\
\hline 5 & Job opportunity (X2.5) & & & & & & & & & & \\
\hline 6 & Unemployment (X2.6) & & & & & & & & & & \\
\hline 7 & Entertainment (X2.7) & & & & & & & & & & \\
\hline 8 & Clothing (X2.8) & & & & & & & & & & \\
\hline 9 & Food (X2.9) & & & & & & & & & & \\
\hline 10 & Home (X2.10) & & & & & & & & & & \\
\hline 11 & Transportation (X2.11) & & & & & & & & & & \\
\hline 12 & Business state (X2.12) & & & & & & & & & & \\
\hline & & & & & & & & & & & \\
\hline III & Cultural (X3) & & & & & & & & & & \\
\hline 1 & $\begin{array}{l}\text { Family's capability to overcome non- } \\
\text { physical problems (X3.1) }\end{array}$ & & & & & & & & & & \\
\hline 2 & Physical emotional control (X3.2) & & & & & & & & & & \\
\hline
\end{tabular}




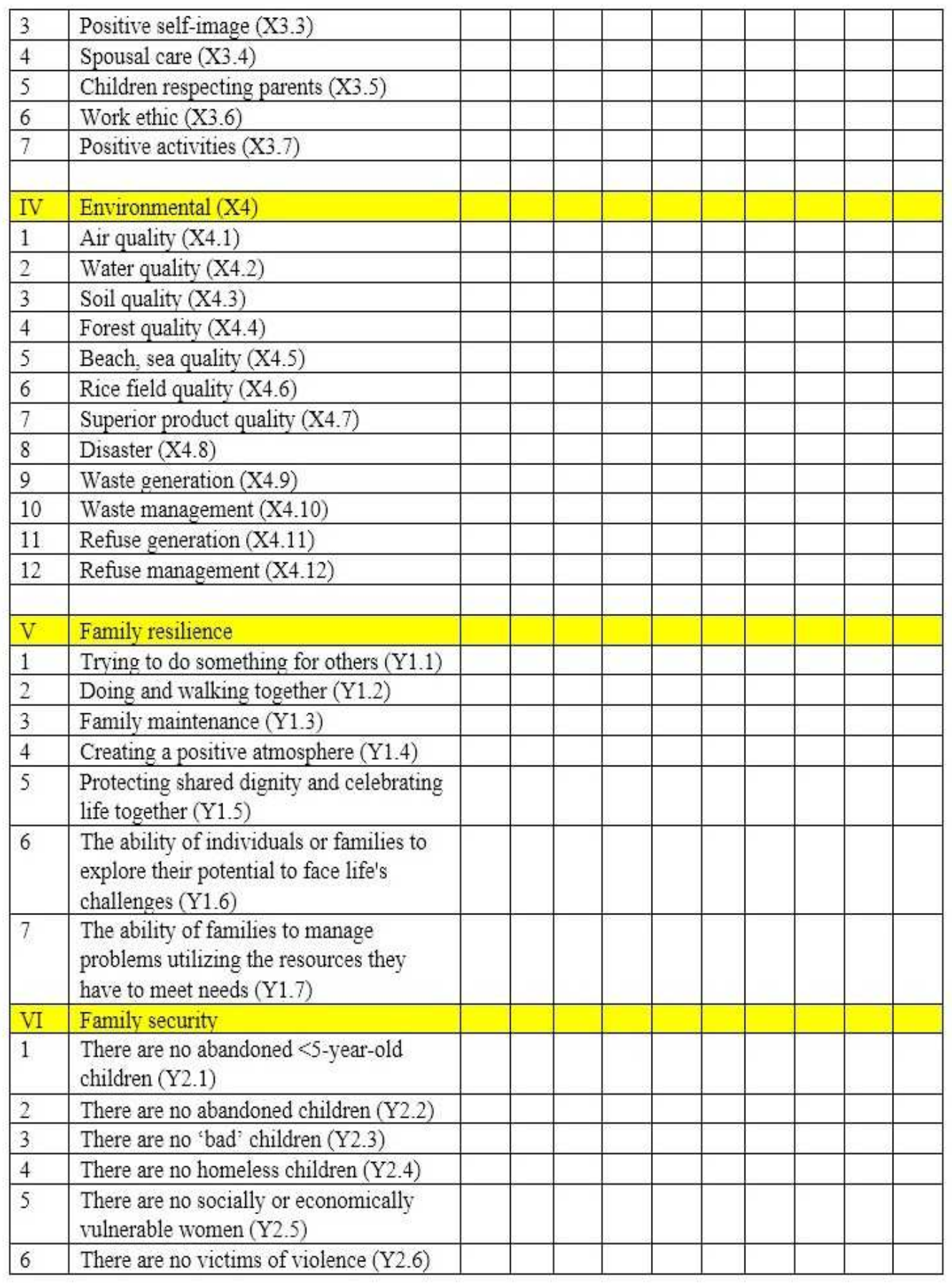




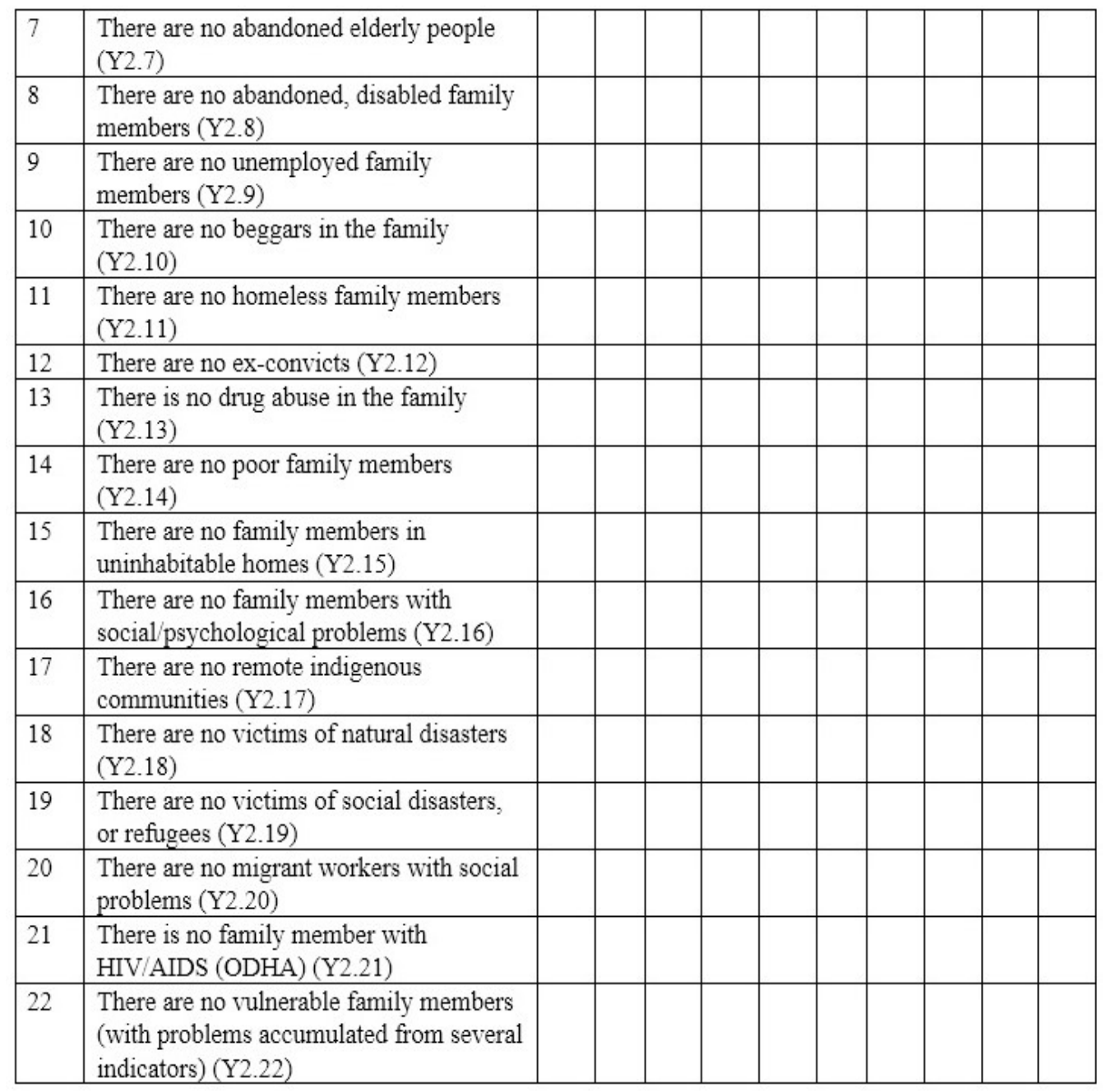

Source: Republik Indonesia (1992).

\subsubsection{Test of Validity and Reliability of the Instrument}

Testing the validity and reliability of the instrument was done through a confirmatory factor analysis. The indicators of a variable may be considered valid if they show a significant loading factor with $\alpha=5 \%$. A research instrument is considered unidimensional valid if it has a value of goodness of fit index (GFI) $>0,90$ and is considered reliable if it has a value of construct reliability $\left(\rho_{\eta}\right)>0,70$.

The instrument validity and reliability tests were carried out in stages if the result of the confirmatory factor analysis was GFI $<0,90$ or if the loading factor of a small indicator $(<$ $0,30)$, then the relevant indicator. 


\subsection{Data Analysis Technique}

The answers obtained from the respondents are in accordance with the predetermined variable values. The analysis was carried out using the Structural Equation Model (SEM) and the smart PLS program package. SEM allows analysis on a series of relationships simultaneously to provide statistical efficiency.

This study used smart PLS 3.2.7 software for data processing. Structural Equation Modeling (SEM) is a method used to cover weaknesses contained in the regression method. According to experts, Structural Equation Modeling (SEM) research methods are divided into two approaches: Covariance Based SEM (CBSEM) and Variance Based SEM or Partial Least Square (PLS) approaches. Partial Least Square is a powerful analysis method as it is not based on many assumptions.

Parameter estimates obtained with PLS can be categorized as follows: First category is the weight estimate used to create a latent variable score. The second reflects the path estimate connecting connects the latent variables, and between the latent variable and indicator block (loading). The third category is related to the means and location of parameters (regression constant values) for indicators and latent variables.

To obtain the three estimates, PLS uses a three-stage iteration process, and each stage results in the following:

a) Generating weight estimate.

b) Generating estimates for inner model and outer model.

c) Generating means and location estimates (constant).

The analysis technique in the PLS method is described as follows:

\subsubsection{Outer model analysis}

a) Convergent Validity is an indicator assessed based on the correlation between item scores/component scores and construct scores, which can be seen from the standardized loading factor illustrating the magnitude of the correlation. The individual reflexive magnitude is considered high if it correlates in $>0.7$ with the construct, whereas according to Chin, as quoted by Imam Ghozali, an outer loading value between $0.5-0.6$ is considered sufficient.

b) Discriminant Validity is a measurement model with reflexive indicators assessed based on cross-loading measurements with constructs. If the correlation of a construct with a measurement item is greater than the size of other constructs, then the block size is better than other blocks.

c) Composite reliability is an indicator to measure a construct in the view of latent variable coefficients. There are two tools to evaluate composite reliability, including internal consistency and Cronbach's alpha. If the value achieved is $>0.70$, then it means the construct has a high reliability.

d) Cronbach's Alpha is a reliability test to strengthen the result of composite reliability. A variable is declared reliable if it has a Cronbach's alpha value $>0.7$. The test conducted above is a test on the outer model for reflective indicators.

Different tests for formative indicators include:

a) Significance of weights 
b) Multicollinearity.

Note: in this study, all indicators are reflective.

\subsubsection{Inner model analysis}

This analysis can be evaluated using R-square for the dependent construct, Stone-Geisser $\mathrm{Q}$ square test for predictive relevance and t-test for the significance of the structural path parameter coefficients. Evaluation of the inner model using PL is done by looking at R-square for each dependent latent variable. Changes in the value of the R-square are used to assess the effect of certain independent latent variables on a dependent latent variable, to find out a substantive effect. Its evaluation can also be done by looking at the predictive value of Qsquare relevance for the constructive model. Q-square measures how well the observational values generated by the model and its estimated parameters. $>0$ Q-square value indicates that the model has a predictive relevance value, whereas $<0$ Q-square value indicates that the model lacks predictive relevance.

In testing the hypotheses, $t$-statistic value and probability value can be considered. To test a hypothesis, the t-statistic value is 1.96 for alpha of $5 \%$. Ha is accepted and $\mathrm{H} 0$ is rejected when $t$-statistic value is $>1.96$. In a probability test, Ha is accepted if the value of $p$ is $<0.05$.

\subsubsection{Hypothesis}

As this is a theory-based model, and the result has not been tested, then theoretically, the following hypotheses apply:

\section{a) Hypothesis 1}

It is assumed that the social variable is reflected in these 20 indicators, including security $\left(\mathrm{X}_{1.1}\right)$, peace $\left(\mathrm{X}_{1.2}\right)$, hope for a better future $\left(\mathrm{X}_{1.3}\right)$, prosperity $\left(\mathrm{X}_{1.4}\right)$, Health $\left(\mathrm{X}_{1.5}\right)$, Progress $\left(\mathrm{X}_{1.6}\right)$, Independence $\left(\mathrm{X}_{1.7}\right)$, Ideal number of children $\left(\mathrm{X}_{1.8}\right)$, Responsibility $\left(\mathrm{X}_{1.9}\right)$, Harmonious living $\left(\mathrm{X}_{1.10}\right)$, Devotion $\left(\mathrm{X}_{1.11}\right)$, Self-reliance $\left(\mathrm{X}_{1.12}\right)$, physical and mental happiness $\left(\mathrm{X}_{1.13}\right)$, education $\left(\mathrm{X}_{1.14}\right)$, spiritual $\left(\mathrm{X}_{1.15}\right)$, division of roles $\left(\mathrm{X}_{1.16}\right)$, support for progress $\left(\mathrm{X}_{1.17}\right)$, family time $\left(\mathrm{X}_{1.18}\right)$, social interaction $\left(\mathrm{X}_{1.19}\right)$, and problem solving $\left(\mathrm{X}_{1.20}\right)$.

\section{b) Hypothesis 2}

It is assumed that the economic variable is reflected in these 12 indicators, including salary $\left(\mathrm{X}_{2.1}\right)$, bonus $\left(\mathrm{X}_{2.2}\right)$, savings $\left(\mathrm{X}_{2.3}\right)$, livelihood $\left(\mathrm{X}_{2.4}\right)$, job opportunity $\left(\mathrm{X}_{2.5}\right)$, unemployment $\left(\mathrm{X}_{2.6}\right)$, entertainment $\left(\mathrm{X}_{2.7}\right)$, clothing $\left(\mathrm{X}_{2.8}\right)$, food $\left(\mathrm{X}_{2.9}\right)$, home $\left(\mathrm{X}_{2.10}\right)$, transportation $\left(\mathrm{X}_{2.11}\right)$, business state $\left(\mathrm{X}_{2.12}\right)$.

\section{c) Hypothesis 3}

It is assumed that the cultural variable is reflected in these 7 indicators, including family's capability to overcome non-physical problems $\left(\mathrm{X}_{3.1}\right)$, physical emotional control $\left(\mathrm{X}_{3.2}\right)$, positive self-image $\left(\mathrm{X}_{3.3}\right)$, spousal care $\left(\mathrm{X}_{3.4}\right)$, children respecting parents $\left(\mathrm{X}_{3.5}\right)$, work ethic $\left(\mathrm{X}_{3.6}\right)$, positive activities $\left(\mathrm{X}_{3.7}\right)$.

\section{d) Hypothesis 4}

It is assumed that the environmental variable is reflected in these 12 indicators, including family's capability in dealing with air quality $\left(\mathrm{X}_{4.1}\right)$, water quality $\left(\mathrm{X}_{4.2}\right)$, soil quality $\left(\mathrm{X}_{4.3}\right)$, forest quality $\left(\mathrm{X}_{4.4}\right)$, beach, sea quality $\left(\mathrm{X}_{4.5}\right)$, rice field quality $\left(\mathrm{X}_{4.6}\right)$, superior product quality 
$\left(\mathrm{X}_{4.7}\right)$ disasters $\left(\mathrm{X}_{4.8}\right)$, waste generation $\left(\mathrm{X}_{4.9}\right)$, waste management $\left(\mathrm{X}_{4.10}\right)$, refuse generation $\left(\mathrm{X}_{4.11}\right)$, refuse management $\left(\mathrm{X}_{4.12}\right)$.

e) Hypothesis 5

It is assumed that the family resilience variable is reflected in these 7 indicators, including: trying to do something for others $\left(\mathrm{Y}_{1.1}\right)$, doing and walking together $\left(\mathrm{Y}_{1.2}\right)$, family maintenance $\left(\mathrm{Y}_{1.3}\right)$, creating a positive atmosphere $\left(\mathrm{Y}_{1.4}\right)$, protecting shared dignity and celebrating life together $\left(\mathrm{Y}_{1.5}\right)$, the ability of individuals or families to explore their potential to face life's challenges $\left(\mathrm{Y}_{1.6}\right)$, the ability of families to manage problems utilizing the resources they have to meet needs $\left(\mathrm{Y}_{1.7}\right)$.

\section{f) Hypothesis 6}

It is assumed that the family adaptability variable is reflected in these 22 indicators, including No abandoned $<5$-year-old children $\left(\mathrm{Y}_{2.1}\right)$, no abandoned children $\left(\mathrm{Y}_{2.2}\right)$, no 'bad' children $\left(\mathrm{Y}_{2.3}\right)$, no homeless children $\left(\mathrm{Y}_{2.4}\right)$, no socially and economically vulnerable women $\left(\mathrm{Y}_{2.5}\right)$, no victims of violence $\left(\mathrm{Y}_{2.6}\right)$, no abandoned elderly people $\left(\mathrm{Y}_{2.7}\right)$, no abandoned, disabled family members $\left(\mathrm{Y}_{2.8}\right)$, no unemployed family members $\left(\mathrm{Y}_{2.9}\right)$, no beggars in the family $\left(\mathrm{Y}_{2.10}\right)$, no homeless family members $\left(\mathrm{Y}_{2.11}\right)$, no ex-convicts $\left(\mathrm{Y}_{2.12}\right)$, no drug abuse $\left(\mathrm{Y}_{2.13}\right)$, no poor family members $\left(\mathrm{Y}_{2.14}\right)$, no family members living in inhabitable homes $\left(\mathrm{Y}_{2.15}\right)$, no family members with social and psychological problems $\left(\mathrm{Y}_{2.16}\right)$, no remote indigenous communities $\left(\mathrm{Y}_{2.17}\right)$, no victims of natural disasters $\left(\mathrm{Y}_{2.18}\right)$, no victims of social disasters/refugees $\left(\mathrm{Y}_{2.19}\right)$, no migrant workers with social problems $\left(\mathrm{Y}_{2.20}\right)$, no family members with HIV/AIDS (ODHA) $\left(\mathrm{Y}_{2.21}\right)$, no vulnerable family members $\left(\mathrm{Y}_{2.22}\right)$.

\section{g) Hypothesis 7}

It is assumed that there is a significantly positive effect of social, economic, cultural and environmental variables on family resilience variable.

\section{h) Hypothesis 8}

It is assumed that there is a significantly positive effect of social, economic, cultural and environmental variables on family adaptability variable.

\section{i) Hypothesis 9}

It is assumed that there is a significantly positive relationship between family resilience and family adaptability [8].

\section{Result and Discussion}

\subsection{Analysis of Confirmatory Factor of the Measurement Model (Outer Model)}

\subsubsection{Social Variable}

Table 3 shows that the cross-loading values of the X1.1 indicator to X1.20 indicator are the greatest. This suggest that the indicators meet the discriminant validity. Therefore, X1.1 $\mathrm{X} 1.20$ as indicators are valid. Additionally, the CR value of this measurement model is 0.953 , which is 0.70 , indicating that X1.1 indicator until X1.20 indicators are valid and reliable in 
reflecting the X1 variable. Therefore, they fit to be used in the analysis of structural model (inner model).

Based on Table 2, the outer loading values of all X1 indicators are more than 0.50 , except for X8 (ideal number of children). Thus, the research instrument is considered meeting the requirements of convergent validity. The following are the indicators, from the most to the least dominant and significant: X1.13 (Physical and mental happiness), X1.6 (progress), X1.10 (harmonious), X1.5 (health), X1.9 (responsibility), X1.12 (self-reliance), X1.11 (devotion), X1.3 (hope for a better future), X1.17 (support for progress), X1.7 (independence), X1.4 (prosperity), X1.15 (spiritual), X1.1 (security), X1.2 (peace), X1.16 (division of roles), X1.14 (problem solving), X1.18 (education), X1.19 (family time). X1.8 (ideal number of children).

$\mathrm{X} 1.13$ (physical and mental happiness) is the most dominant indicator with the largest value of outer loading. This does not imply that people do not feel physical and mental happiness. This indicator means a strong social state. Society needs a lot of motivational programs as the most dominant social indicator is inner and outer happiness.

Table 2. Convergent Validity (Outer Loading) of Social Variable Indicator

\begin{tabular}{|c|c|c|c|}
\hline Indicator & Outer Loading $(\mathrm{O})$ & Ranking & Indicator name \\
\hline & \multicolumn{3}{|l|}{ Significant } \\
\hline $\mathrm{X} 1.13$ & 0.810 & 1 & Physical and mental happiness \\
\hline $\mathrm{X} 1.6$ & 0.806 & 2 & Progress \\
\hline $\mathrm{X} 1.10$ & 0.799 & 3 & Harmonious living \\
\hline $\mathrm{X} 1.5$ & 0.795 & 4 & Health \\
\hline $\mathrm{X} 1.9$ & 0.782 & 5 & Responsibility \\
\hline $\mathrm{X} 1.12$ & 0.777 & 6 & Independence \\
\hline $\mathrm{X} 1.11$ & 0.770 & 7 & Devotion \\
\hline $\mathrm{X} 1.3$ & 0.763 & 8 & $\begin{array}{l}\text { Hope for a better future in } \\
\text { realizing physical well-being } \\
\text { and inner happiness }\end{array}$ \\
\hline $\mathrm{X} 1.17$ & 0.762 & 9 & Support for progress \\
\hline $\mathrm{X} 1.7$ & 0.748 & 10 & Self-reliance \\
\hline $\mathrm{X} 1.4$ & 0.728 & 11 & Prosperity \\
\hline $\mathrm{X} 1.15$ & 0.723 & 12 & Spiritual \\
\hline $\mathrm{X} 1.1$ & 0.717 & 13 & Security \\
\hline $\mathrm{X} 1.2$ & 0.714 & 14 & Peace \\
\hline $\mathrm{X} 1.16$ & 0.695 & 15 & Division of roles \\
\hline $\mathrm{X} 1.20$ & 0.650 & 16 & Problem solving \\
\hline $\mathrm{X} 1.14$ & 0.631 & 17 & Education \\
\hline $\mathrm{X} 1.18$ & 0.628 & 18 & Family time \\
\hline \multirow[t]{2}{*}{$\mathrm{X} 1.19$} & 0.628 & 19 & Social interaction \\
\hline & \multicolumn{3}{|l|}{ Insignificant } \\
\hline $\mathrm{X} 1.8$ & 0.117 & 20 & $\begin{array}{l}\text { Ideal number of children } \\
\text { (insignificant) }\end{array}$ \\
\hline
\end{tabular}


Table 3. Discriminant Validity (Cross Loading) and Reliability (Composite Reliability) of Social Variable

\begin{tabular}{|c|c|c|c|c|c|c|c|}
\hline & $\mathrm{X} 1$ & $\mathrm{X} 2$ & $\mathrm{X} 3$ & $\mathrm{X} 4$ & $\mathrm{X} 5$ & $\mathrm{X} 6$ & CR \\
\hline $\mathrm{X} 1.1$ & 0.717 & 0.338 & 0.516 & 0.322 & 0.475 & 0.340 & \multirow{20}{*}{0.953} \\
\hline $\mathrm{X} 1.2$ & 0.714 & 0.324 & 0.505 & 0.305 & 0.510 & 0.370 & \\
\hline $\mathrm{X} 1.3$ & 0.763 & 0.409 & 0.548 & 0.330 & 0.590 & 0.299 & \\
\hline $\mathrm{X} 1.4$ & 0.728 & 0.427 & 0.482 & 0.331 & 0.457 & 0.292 & \\
\hline $\mathrm{X} 1.5$ & 0.795 & 0.425 & 0.560 & 0.350 & 0.551 & 0.368 & \\
\hline $\mathrm{X} 1.6$ & 0.806 & 0.473 & 0.579 & 0.385 & 0.558 & 0.372 & \\
\hline $\mathrm{X} 1.7$ & 0.748 & 0.428 & 0.520 & 0.327 & 0.504 & 0.315 & \\
\hline X1.8 & 0.117 & 0.009 & 0.077 & 0.088 & 0.046 & 0.031 & \\
\hline X1.9 & 0.782 & 0.407 & 0.647 & 0.307 & 0.601 & 0.331 & \\
\hline $\mathrm{X} 1.10$ & 0.799 & 0.402 & 0.574 & 0.325 & 0.574 & 0.349 & \\
\hline X1.11 & 0.770 & 0.330 & 0.572 & 0.342 & 0.556 & 0.383 & \\
\hline $\mathrm{X} 1.12$ & 0.777 & 0.421 & 0.560 & 0.342 & 0.531 & 0.275 & \\
\hline $\mathrm{X} 1.13$ & 0.810 & 0.410 & 0.596 & 0.340 & 0.591 & 0.335 & \\
\hline X1.14 & 0.631 & 0.435 & 0.479 & 0.340 & 0.485 & 0.208 & \\
\hline $\mathrm{X} 1.15$ & 0.723 & 0.363 & 0.533 & 0.306 & 0.510 & 0.381 & \\
\hline $\mathrm{X} 1.16$ & 0.695 & 0.330 & 0.540 & 0.328 & 0.501 & 0.349 & \\
\hline $\mathrm{X} 1.17$ & 0.762 & 0.442 & 0.572 & 0.324 & 0.554 & 0.262 & \\
\hline X1.18 & 0.628 & 0.288 & 0.454 & 0.252 & 0.438 & 0.289 & \\
\hline $\mathrm{X} 1.19$ & 0.628 & 0.339 & 0.453 & 0.289 & 0.496 & 0.306 & \\
\hline $\mathrm{X} 1.20$ & 0.650 & 0.325 & 0.515 & 0.318 & 0.499 & 0.300 & \\
\hline
\end{tabular}

\subsubsection{Economic Variable (X2)}

Table 4. Convergent Validity (Outer Loading) of Indicators of Institutional Variable (K)

\begin{tabular}{|l|c|c|l|}
\hline \multicolumn{1}{|c|}{ Indicator } & Outer Loading (O) & Ranking & \multicolumn{1}{c|}{ Indicator Name } \\
\hline X2.9 & 0.851 & 1 & Food \\
\hline X2.8 & 0.825 & 2 & Clothing \\
\hline X2.10 & 0.773 & 3 & Home \\
\hline X2.7 & 0.742 & 4 & Entertainment \\
\hline X2.11 & 0.654 & 5 & Transportation \\
\hline X2.1 & 0.587 & 6 & Salary \\
\hline X2.6 & 0.524 & 7 & Unemployment \\
\hline X2.3 & 0.523 & 8 & Savings \\
\hline X2.2 & 0.518 & 9 & Bonus \\
\hline X2.4 & 0.514 & 10 & Livelihood \\
\hline X2.5 & 0.508 & 11 & Job opportunity \\
\hline X2.12 & 0.505 & 12 & Business state \\
\hline
\end{tabular}

Based on Table 4, the outer loading values of all X2 indicators are greater than 0.50 . This means that the research instrument has met the requirement of convergent validity. The following are the indicators from the most to the least dominant: X2.9 (food), X2.8 (clothing), 
X2.10 (food), X2.7 (entertainment), X2.11 (transportation), X2.1 (salary), X2.6 (unemployment), X2.3 (savings), X2.2 (bonus), X2.4 (livelihood), X2.5 (job opportunity), $\mathrm{X} 2.12$ (business state).

Table 5. Discriminant Validity (Cross Loading) and Reliability (Composite Reliability) of Economic Variable

\begin{tabular}{|c|c|c|c|c|c|c|c|}
\hline & $\mathrm{X} 1$ & $\mathrm{X} 2$ & X3 & $\mathrm{X} 4$ & Y1 & Y2 & $\mathrm{CR}$ \\
\hline $\mathrm{X} 1.1$ & 0.310 & 0.587 & 0.236 & 0.224 & 0.248 & 0.082 & \multirow[t]{12}{*}{0.889} \\
\hline $\mathrm{X} 1.2$ & 0.132 & 0.518 & 0.085 & 0.141 & 0.106 & -0.080 & \\
\hline $\mathrm{X} 1.3$ & 0.132 & 0.523 & 0.123 & 0.146 & 0.099 & -0.059 & \\
\hline $\mathrm{X} 1.4$ & 0.177 & 0.514 & 0.150 & 0.152 & 0.137 & -0.066 & \\
\hline $\mathrm{X} 1.5$ & 0.212 & 0.508 & 0.216 & 0.166 & 0.163 & -0.046 & \\
\hline $\mathrm{X} 1.6$ & 0.257 & 0.524 & 0.279 & 0.336 & 0.292 & 0.129 & \\
\hline $\mathrm{X} 1.7$ & 0.380 & 0.742 & 0.406 & 0.250 & 0.406 & 0.203 & \\
\hline $\mathrm{X} 1.8$ & 0.483 & 0.825 & 0.488 & 0.336 & 0.447 & 0.238 & \\
\hline X1.9 & 0.514 & 0.851 & 0.504 & 0.314 & 0.438 & 0.210 & \\
\hline $\mathrm{X} 1.10$ & 0.429 & 0.773 & 0.401 & 0.260 & 0.368 & 0.185 & \\
\hline $\mathrm{X} 1.11$ & 0.334 & 0.654 & 0.281 & 0.234 & 0.309 & 0.104 & \\
\hline $\mathrm{X} 1.12$ & 0.130 & 0.505 & 0.154 & 0.105 & 0.183 & -0.022 & \\
\hline
\end{tabular}

Based on Table 5, the largest cross-loading value of X2.1-X2.12 is indicated by the X2 variable. This suggests that the indicators fulfill the requirement of discriminant validity. Thus, they are declared valid. Additionally, the CR value of this measurement model is 0.889 , which is more than 0.70 , hence their validity and reliability. The most dominant indicator reflected in economic variables is food.

\subsubsection{Cultural (X3)}

Based on Table 6, all indicators show values of more than 0.50 , thus meeting the requirements of convergent validity. The most dominant indicators reflecting cultural variable include X3.3 and X3.7, for they have the largest outer loading values.

Table 6. Convergent Validity (Outer Loading) of Indication of Cultural Variabel (X3)

\begin{tabular}{|l|c|c|c|}
\hline \multicolumn{1}{|c|}{ Indicator } & $\begin{array}{c}\text { Outer Loading } \\
(0)\end{array}$ & Ranking & Indicator Name \\
\hline X3.3 & 0.891 & 1 & Positive self-image \\
\hline X3.7 & 0.825 & 2 & Positive activities \\
\hline X3.2 & 0.823 & 3 & Physical emotional control \\
\hline X3.6 & 0.820 & 4 & Work ethic \\
\hline & & & Family's capability to overcome non-physical \\
X3.1 & 0.755 & 5 & Children respecting parents \\
\hline X3.5 & 0.743 & 6 & Spousal care \\
\hline X3.4 & 0.671 & 7 &
\end{tabular}


Tabel 7. Discriminant Validity (Cross Loading) and Reliability (Composite Reliability) of Cultural Variabel (X2)

\begin{tabular}{|c|c|c|c|c|c|c|c|}
\hline & $\mathrm{X} 1$ & $\mathrm{X} 2$ & $\mathrm{X} 3$ & $\mathrm{X} 4$ & $\mathrm{Y1}$ & Y2 & $\mathrm{CR}$ \\
\hline X3.1 & 0.618 & 0.435 & 0.755 & 0.309 & 0.599 & 0.317 & \multirow[t]{7}{*}{0.921} \\
\hline $\mathrm{X} 3.2$ & 0.609 & 0.433 & 0.823 & 0.368 & 0.673 & 0.361 & \\
\hline $\mathrm{X} 3.3$ & 0.634 & 0.451 & 0.891 & 0.395 & 0.652 & 0.378 & \\
\hline X3.4 & 0.511 & 0.352 & 0.671 & 0.320 & 0.493 & 0.271 & \\
\hline $\mathrm{X} 3.5$ & 0.567 & 0.291 & 0.743 & 0.321 & 0.549 & 0.345 & \\
\hline X3.6 & 0.564 & 0.459 & 0.820 & 0.365 & 0.604 & 0.313 & \\
\hline X3.7 & 0.559 & 0.390 & 0.825 & 0.417 & 0.626 & 0.348 & \\
\hline
\end{tabular}

Table 7 shows that X2.1-X2.7 have great cross-loading values. This shows that the indicators fulfill discriminant validity requirement. Therefore, the indicators are valid and reliable. Additionally, the $\mathrm{CR}$ value of this measurement model is 0.921 , which is more than 0.70 .

\subsubsection{Environmental Variable (X4)}

Table 8. Convergent Validity (Outer Weights) of Indicators of Environmental Variable (X4)

\begin{tabular}{|l|c|c|l|l|}
\hline \multicolumn{1}{|c|}{ Indicator } & $\begin{array}{c}\text { Outer Loading } \\
(\mathrm{O})\end{array}$ & Ranking & \multicolumn{1}{|c|}{ Indicator Name } & \\
\hline $\mathrm{X} 4.3$ & 0.731 & 1 & Soil quality & Significant \\
\hline $\mathrm{X} 4.10$ & 0.702 & 2 & Waste management & Significant \\
\hline $\mathrm{X} 4.11$ & 0.676 & 3 & Refuse generation & Significant \\
\hline $\mathrm{X} 4.9$ & 0.672 & 4 & Waste generation & Significant \\
\hline $\mathrm{X} 4.1$ & 0.662 & 5 & Air quality & Significant \\
\hline $\mathrm{X} 4.12$ & 0.640 & 6 & Refuse generation & Significant \\
\hline $\mathrm{X} 4.4$ & 0.582 & 7 & Forest quality & Significant \\
\hline $\mathrm{X} 4.6$ & 0.567 & 8 & Rice field quality & Significant \\
\hline $\mathrm{X} 4.5$ & 0.508 & 9 & Beach, sea quality & Significant \\
\hline $\mathrm{X} 4.2$ & 0.505 & 10 & Water quality & Significant \\
\hline $\mathrm{X} 4.8$ & 0.494 & 11 & Disasters & Insignificant \\
\hline $\mathrm{X} 4.7$ & 0.456 & 12 & Superior product quality & Insignificant \\
\hline
\end{tabular}

Based on Table 8 , all outer loading values of indicators of $\mathrm{X} 4$ are more than 0.50 , except for X4.8 and X4.7. Thus, all except X4.8 and X4.7 have met the requirement of convergent validity. The most dominant indicators include X4.3 and X4.10 for they have the largest outer loading values. 
Table 9. Discriminant Validity (Cross Loading) of Environmental Variable (X4)

\begin{tabular}{|c|c|c|c|c|c|c|c|}
\hline & $\mathrm{X} 1$ & $\mathrm{X} 2$ & $\mathrm{X} 3$ & $\mathrm{X} 4$ & $\mathrm{Y} 1$ & $\mathrm{Y} 2$ & $\mathrm{CR}$ \\
\hline $\mathrm{X} 4.1$ & 0.377 & 0.236 & 0.380 & 0.662 & 0.402 & 0.199 & \multirow[t]{11}{*}{0.872} \\
\hline $\mathrm{X} 4.2$ & 0.175 & 0.095 & 0.220 & 0.505 & 0.267 & 0.129 & \\
\hline $\mathrm{X} 4.3$ & 0.387 & 0.252 & 0.438 & 0.731 & 0.451 & 0.282 & \\
\hline $\mathrm{X} 4.4$ & 0.257 & 0.199 & 0.240 & 0.582 & 0.270 & 0.175 & \\
\hline $\mathrm{X} 4.5$ & 0.183 & 0.218 & 0.180 & 0.508 & 0.150 & 0.102 & \\
\hline $\mathrm{X} 4.6$ & 0.154 & 0.183 & 0.166 & 0.567 & 0.213 & 0.081 & \\
\hline $\mathrm{X} 4.7$ & 0.172 & 0.113 & 0.202 & 0.456 & 0.259 & 0.158 & \\
\hline X4.8 & 0.299 & 0.115 & 0.297 & 0.494 & 0.292 & 0.280 & \\
\hline $\mathrm{X} 4.10$ & 0.209 & 0.324 & 0.226 & 0.672 & 0.236 & 0.161 & \\
\hline $\mathrm{X} 4.11$ & 0.278 & 0.328 & 0.267 & 0.702 & 0.282 & 0.142 & \\
\hline X.12 & 0.280 & 0.333 & 0.239 & 0.676 & 0.298 & 0.172 & \\
\hline
\end{tabular}

Table 9 shows that the cross-loading values of indicators $\mathrm{X} 4.1-\mathrm{X} 4.12$ are great. This indicates that the indicators fulfill the requirement of discriminant validity, hence its validity. Additionally, the CR value of this measurement model is 0.872 , which is more than 0.70 , declaring them valid and reliable.

\subsubsection{Family Resilience Variable}

Table 10. Convergent Validity (Outer Loading) of Indicators of Family Resilience Variable (Y1)

\begin{tabular}{|l|c|c|l|}
\hline \multicolumn{1}{|c|}{ Indicator } & $\begin{array}{c}\text { Outer Loading } \\
(\mathrm{O})\end{array}$ & Ranking & \multicolumn{1}{|c|}{ Indicator Name } \\
\hline Y1.3 & 0.879 & 1 & Family maintenance \\
\hline Y1.2 & 0.874 & 2 & Doing and walking together \\
\hline Y1.5 & 0.863 & 3 & $\begin{array}{l}\text { Protecting shared dignity and celebrating } \\
\text { life together }\end{array}$ \\
\hline Y1.7 & 0.852 & 4 & $\begin{array}{l}\text { The ability of families to manage } \\
\text { problems utilizing the resources they have } \\
\text { to meet needs }\end{array}$ \\
\hline Y1.6 & 0.840 & 5 & $\begin{array}{l}\text { The ability of individuals or families to } \\
\text { explore their potential to face life's } \\
\text { challenges }\end{array}$ \\
\hline Y1.4 & 0.809 & 6 & Creating a positive atmosphere \\
\hline Y1.1 & 0.792 & 7 & Trying to do something for others \\
\hline
\end{tabular}

Based on Table 10, all outer loading values of indicators of family resilience (Y1) are greater than 0.50 , hence their eligibility for further analysis. 
Table 11. Discriminant Validity (Cross Loading) and Reliability (Composite Reliability) of Family Resilience Variable (Y1)

\begin{tabular}{|c|c|c|c|c|c|c|c|}
\hline & $\mathrm{X} 1$ & $\mathrm{X} 2$ & $\mathrm{X} 3$ & $\mathrm{X} 4$ & Y1 & $\mathrm{Y} 2$ & CR \\
\hline Y1.1 & 0.532 & 0.415 & 0.633 & 0.413 & 0.792 & 0.380 & \multirow{7}{*}{0.946} \\
\hline Y1.2 & 0.632 & 0.387 & 0.682 & 0.472 & 0.874 & 0.422 & \\
\hline Y1.3 & 0.619 & 0.390 & 0.613 & 0.408 & 0.879 & 0.411 & \\
\hline Y1.4 & 0.595 & 0.312 & 0.614 & 0.455 & 0.809 & 0.412 & \\
\hline Y1.5 & 0.655 & 0.406 & 0.672 & 0.393 & 0.863 & 0.497 & \\
\hline Y1.6 & 0.610 & 0.489 & 0.647 & 0.395 & 0.840 & 0.351 & \\
\hline $\mathrm{Y} 1.7$ & 0.590 & 0.478 & 0.632 & 0.396 & 0.852 & 0.336 & \\
\hline
\end{tabular}

Table 11 shows that the cross-loading values of Y1.1-Y1.7 are great. This indicates that the indicators fulfill discriminant validity requirement, hence their validity. Additionally, the CR value of this measurement model is 0.946 , which is more than 0.70 , declaring them valid and reliable.

\subsubsection{Family Adaptability Variable}

Table 12. Convergent Validity (Outer Loading) of Indicators of Family Adaptability Variable (Y2)

\begin{tabular}{|l|c|c|l|}
\hline \multicolumn{1}{|c|}{ Indicator } & $\begin{array}{c}\text { Outer } \\
\text { Loading }(\mathrm{O})\end{array}$ & Ranking & \multicolumn{1}{c|}{ Indicator Name } \\
\hline Y2.9 & 0.875 & 1 & Unemployed family members \\
\hline Y2.12 & 0.842 & 2 & Ex-convicts \\
\hline Y2.20 & 0.840 & 3 & Migrant workers with social problems \\
\hline Y2.16 & 0.837 & 4 & $\begin{array}{l}\text { Family members with social/psychological } \\
\text { problems }\end{array}$ \\
\hline Y2.6 & 0.836 & 5 & Victims of violence \\
\hline Y2.7 & 0.836 & 6 & Abandoned elderly people \\
\hline Y2.19 & 0.826 & 7 & Victims of social disorder/refugees \\
\hline Y2.1 & 0.820 & 8 & Abandoned <5-year-old children \\
\hline Y2.21 & 0.817 & 9 & Family members with HIV/AIDS \\
\hline Y2.11 & 0.815 & 10 & Homeless family members \\
\hline Y2.8 & 0.811 & 11 & Abandoned disabled people \\
\hline Y2.2 & 0.808 & 12 & Abandoned child \\
\hline Y2.13 & 0.801 & 13 & Drug abuse \\
\hline Y2.10 & 0.796 & 14 & Beggars \\
\hline Y2.4 & 0.773 & 15 & Homeless children \\
\hline Y2.3 & 0.758 & 16 & 'Bad' children \\
\hline Y2.22 & 0.750 & 17 & Vulnerable family members \\
\hline Y2.5 & 0.741 & 18 & Economically and socially vulnerable women \\
\hline Y2.17 & 0.735 & 19 & Remote indigenous communities \\
\hline Y2.15 & 0.729 & 20 & Family members in unhabitable homes \\
\hline Y2.18 & 0.648 & 21 & Victims of natural disasters \\
\hline Y2.14 & 0.590 & 22 & Poor family members \\
\hline & & &
\end{tabular}


Based on Table 12, all indicators show outer loading values of above 0.50 . This means that they can be used for further analysis. The most dominant indicators include Y2.9 and Y2.12 for they have the largest outer loading values.

Table 13. Discriminant Validity (Cross Loading) and Reliability (Composite Reliability) of Family Adaptability Variable

\begin{tabular}{|l|l|l|l|l|l|l|l|}
\hline & $\mathrm{X} 1$ & $\mathrm{X} 2$ & $\mathrm{X} 3$ & $\mathrm{X} 4$ & $\mathrm{Y} 1$ & $\mathrm{Y} 2$ & \multirow{2}{*}{$\mathrm{CR}$} \\
\hline $\mathrm{y} 2.1$ & 0.381 & 0.182 & 0.379 & 0.261 & 0.402 & 0.820 & \multirow{2}{*}{0.973} \\
\hline Y2.2 & 0.364 & 0.203 & 0.375 & 0.284 & 0.394 & 0.808 \\
\hline Y2.3 & 0.353 & 0.161 & 0.361 & 0.227 & 0.363 & 0.758 \\
\hline Y2.4 & 0.343 & 0.168 & 0.346 & 0.225 & 0.360 & 0.773 \\
\hline Y2.6 & 0.369 & 0.192 & 0.349 & 0.297 & 0.392 & 0.741 \\
\hline Y2.7 & 0.398 & 0.188 & 0.361 & 0.248 & 0.406 & 0.836 \\
\hline Y2.8 & 0.321 & 0.077 & 0.338 & 0.227 & 0.399 & 0.811 \\
\hline Y2.9 & 0.391 & 0.140 & 0.377 & 0.230 & 0.424 & 0.875 \\
\hline Y2.10 & 0.315 & 0.142 & 0.277 & 0.226 & 0.337 & 0.796 \\
\hline Y2.11 & 0.289 & 0.127 & 0.276 & 0.174 & 0.315 & 0.815 \\
\hline Y2.12 & 0.384 & 0.124 & 0.367 & 0.213 & 0.371 & 0.842 \\
\hline Y2.13 & 0.345 & 0.129 & 0.323 & 0.264 & 0.357 & 0.801 \\
\hline Y2.14 & 0.337 & 0.295 & 0.334 & 0.304 & 0.376 & 0.590 \\
\hline Y2.15 & 0.392 & 0.241 & 0.366 & 0.299 & 0.446 & 0.729 \\
\hline Y2.16 & 0.386 & 0.180 & 0.360 & 0.239 & 0.411 & 0.837 \\
\hline Y2.17 & 0.323 & 0.158 & 0.278 & 0.189 & 0.335 & 0.735 \\
\hline Y2.18 & 0.201 & 0.107 & 0.188 & 0.116 & 0.286 & 0.648 \\
\hline Y2.19 & 0.284 & 0.097 & 0.264 & 0.209 & 0.335 & 0.826 \\
\hline Y2.20 & 0.322 & 0.118 & 0.300 & 0.208 & 0.353 & 0.840 \\
\hline Y2.21 & 0.349 & 0.100 & 0.328 & 0.227 & 0.364 & 0.817 \\
\hline Y2.22 & 0.328 & 0.152 & 0.309 & 0.240 & 0.350 & 0.750 & \multirow{2}{*}{} \\
\hline & & & & & 0.302 & 0.424 & 0.836 \\
\hline
\end{tabular}

Table 13 shows that the cross-loading values of Y2.1-Y2.22 are great. This shows that the indicators have met the requirement of discriminant validity, hence their validity. Additionally, the CR value of this measurement model is 0.973 , which is more than 0.70 , declaring them valid and reliable.

\subsection{Goodness-of-Fit of Structural Model (Inner Model)}

After obtaining a valid and reliable latent variable measurement model, the measurement results are then used in the analysis of structural model or inner model. The goodness of fit of inner model of each endogenous latent variable is determined based on the R-square value or the coefficient of determination. The overall goodness of fit of structural model is measured by $\mathrm{Q}^{2}$ predictive relevance. A structural model is declared good fit if its $\mathrm{Q}^{2}$ predictive relevance is $>0.50$. R-square values of the structural model are presented in following table. 
Table 14. R-Square of Endogenous Latent Variable of Structural Model

\begin{tabular}{|l|c|}
\hline \multicolumn{1}{|c|}{ Endogenous Latent Variables } & R Square \\
\hline Family Resilience (Y1) & 0,652 \\
\hline Family Adaptability (Y2) & 0,261 \\
\hline
\end{tabular}

Based on the R-square values of the two endogenous latent variables presented in Table 13 , the following $\mathrm{Q}^{2}$ predictive relevance is obtained:

$$
\mathrm{Q}^{2}=1-(1-0.649)(1-0.253)=0.738 \sim 73.8 \%
$$

This value indicates that approximately 73.8 of latent endogenous variable in the structural model can be explained by the model itself, while the remaining 26.2 shall be explained by other variables outside the model and error. The predictive relevance Q2 value obtained is more than 0.50 , declaring it a good fit.

\subsection{Testing the Path Coefficient Hypothesis and Interpretation}

Based on the goodness of fit of the previous structural model, the structural model was a Good Fit. This means that the model is feasible to be used in hypotheses testing to determine the relationship between variables. An exogenous latent variable is considered influential on the endogenous latent variable if t-statistic is greater than 1.96 or less than -1.96 . The result of hypotheses testing is presented in Table 15.

Table 15. Hypothesis Testing Result for the Effect Relationship among Latent Variables

\begin{tabular}{|l|r|r|r|r|}
\hline $\begin{array}{c}\text { Relationship of } \\
\text { Latent } \\
\text { Variables }\end{array}$ & $\begin{array}{c}\text { Original } \\
\text { Sample (O) }\end{array}$ & \multicolumn{1}{|c|}{$\begin{array}{c}\text { Standard } \\
\text { Deviation } \\
\text { (STDEV) }\end{array}$} & $\begin{array}{c}\text { T Statistics } \\
(\mid \mathbf{O} / \text { STDEV })\end{array}$ & Description \\
\hline $\mathrm{X} 1$-> Y1 & 0.303 & 0.050 & 6.076 & Significant \\
\hline $\mathrm{X} 1$-> Y2 & 0.203 & 0.080 & 2.523 & Significant \\
\hline $\mathrm{X} 2$-> Y1 & 0.041 & 0.036 & 1.128 & Insignificant \\
\hline $\mathrm{X} 2$-> Y2 & -0.111 & 0.050 & 2.222 & Significant \\
\hline $\mathrm{X} 3$-> Y1 & 0.457 & 0.053 & 8.653 & Significant \\
\hline $\mathrm{X} 3$-> Y2 & 0.080 & 0.071 & 1.122 & Insignificant \\
\hline $\mathrm{X} 4$-> Y1 & 0.138 & 0.037 & 3.780 & Significant \\
\hline $\mathrm{X} 4$-> Y2 & 0.046 & 0.048 & 0.951 & Insignificant \\
\hline $\mathrm{Y} 1$-> Y2 & 0.303 & 0.087 & 3.472 & Significant \\
\hline
\end{tabular}

Theory of structural equation model:

Endogenous Variable $=$ Exogenous Variable + Endogenous Variable + Error

Family Resilience $(\mathrm{Y} 1)=\beta_{1} \mathrm{X}_{1}+\beta_{2} \mathrm{X}_{2}+\beta_{3} \mathrm{X}_{3}+\beta_{4} \mathrm{X}_{4}+\mathrm{e}_{1}$

Family Adaptability $\left(Y_{2}\right)=\beta_{5} Y_{1}+\beta_{6} X_{1}+\beta_{7} X_{2}+\beta_{8} X_{3}+\beta_{9} X_{4}+e_{2}$

Where: $\beta=$ path coefficient of each variable, $\mathrm{e}=$ error, $\mathrm{X} 1=$ social, $\mathrm{X} 2=$ economic, $\mathrm{X} 3=$ cultural, $\mathrm{X} 4$

$=$ environmental, $\mathrm{Y} 1=$ family resilience and $\mathrm{Y} 2$ = family adaptability 
The structural equation model resulting from the analysis:

$\mathrm{Y} 1=0,303 \mathrm{X} 1+0,041 \mathrm{X} 2+0,457 \mathrm{X} 3+0,138 \mathrm{X} 4+\mathrm{e}_{1}$

$\mathrm{Y} 2=0,303 \mathrm{Y} 1+0,203 \mathrm{X} 1-0,111 \mathrm{X} 2+0,080 \mathrm{X} 3+0,046+\mathrm{e}_{2}$

\section{Conclusion and Suggestions}

\subsection{Conclusion}

a) Hypothesis 1 , only 1 indicator is not proven to reflect the social variable (the ideal number of children) $\left(\mathrm{X}_{1.8}\right)$

b) Hypothesis 2, all indicators evidently reflect economic variable

c) Hypothesis 3, all indicators evidently reflect cultural variable

d) Hypothesis 4, 2 indicators do not evidently reflect environmental variable (superior product quality $\left(\mathrm{X}_{4.7}\right)$, disasters $\left(\mathrm{X}_{4.8}\right)$ )

e) Hypothesis 5, all indicators evidently reflect family resilience variable

f) Hypothesis 6, all indicators evidently reflect family adaptability variable

g) Hypothesis 7, there is evidently a positive and significant relationship between social, economic, cultural and environmental variables and family resilience variable

h) Hypothesis 8, there is no evidence of positive and significant relationship between social, economic, cultural and environmental variables and family adaptability variable

i) Hypothesis 9, there is evidently a positive and significant relationship between family resilience and family adaptability.

j) Recommended model:

$$
\begin{aligned}
& \mathrm{Y} 1=0,297 \mathrm{X} 1+0,045 \mathrm{X} 2+0,456 \mathrm{X} 3+0,0145 \mathrm{X} 4+\mathrm{e}_{1} \\
& \mathrm{Y} 2=0,292 \mathrm{Y} 1+0,200 \mathrm{X} 1-0,113 \mathrm{X} 2+0,075 \mathrm{X} 3+0,080 \mathrm{X} 4+\mathrm{e}_{2}
\end{aligned}
$$

Where:

$\beta=$ path coefficient of each variable, $\mathrm{e}=$ error, $\mathrm{X} 1=$ social, $\mathrm{X} 2=$ economic, $\mathrm{X} 3=$ cultural, $\mathrm{X} 4$ = environmental, $\mathrm{Y} 1=$ family resilience and $\mathrm{Y} 2$ = family adaptability

\subsection{Suggestions}

a) Cooperatives capable to develop savings and loan quickly need to be expanded Reviewing bonuses as good performance has become a regular program in various

b) companies, thus the regulations related to bonuses need to be prepared, as some kind of motivation to maximize HR potential

c) Creating livelihood in business while maintaining social and environmental balance

d) The Education Office to prepare a curriculum stimulating students to be skilled at creating jobs rather than looking for jobs. The future employment prospect is the industry-based 4.0.

e) Department of Industry and Trade to make a breakthrough for the export of superior products from Pasuruan. Indonesia export sector emphasizes on processed products.

f) The Department of Fisheries, Animal Husbandry, Forestry, etc. to adjust the economic recommendation under its authority and responsibility 
g) The government through all Offices related to the performance of cultural aspects to maintain the implementation of their programs.

h) The local government with environmental agencies to improve waste management and handle waste generation by employing a monitoring report involving relevant stakeholders

\section{References}

[1] Pemerintah Indonesia, UU No.87 Tahun 2014 tentang Perkembangan Kependudukan dan Pembangunan Keluarga, Keluarga Berencana, dan Sistem Informasi Keluarga. Lembaran RI Tahun 2014. Jakarta: Sekretariat Negara, 2014.

[2] J. M. White and D. M. Klein, "Family Theories .(2008)." Thousand Oaks, CA: Sage Publications, Inc.

[3] E. M. Duvall and R. Hill, When you marry. Boston, MA: D. C. Heath and Co, 1945.

[4] B. Supomo and N. Indriantoro, "Metodologi Penelitian Bisnis Untuk Akuntansi dan Manajemen," Yogyakarta BPFE Yogyakarta, 2002.

[5] Sugiyono, Metode Penelitian Kuantitatif, Kualitatif dan R\&D. Bandung: Alfabeta, 2006.

[6] Notobroto, Teknik Sampling Untuk Penelitian Non Eksperimental Dan Eksperimental. Surabaya, 2004.

[7] A. Ferdinand, "Structural Equation Modeling Dalam Penelitian Manajemen: Aplikasi ModelModel Rumit Dalam Penelitian Untuk.” Tesis Magister dan Disertasi Doktor, 2005.

[8] H. Riniwati, N. Harahab, and Z. Abidin, "A vulnerability analysis of coral reefs in coastal ecotourism areas for conservation management," Diversity, vol. 11, no. 7, p. 107, 2019. 